\title{
The Role of Mathematical Methods in the Digitalization of the Tourism Business
}

\author{
Keferova I.Kh. \\ Kabardino - Balkarian state agrarian University \\ Nalchik, Russia \\ rayakerefova@gmail.com
}

\begin{abstract}
This article analyzes the opportunities that the rapid development of digital technology opens for tourist business. It is shown that the digital tourism has many components, and launch all its forms and the successful further development and functioning of capable tourism as an important sector of the economy, to bring to the world level. The solution of this global problem in the field of tourism will give a real chance of a strong economic growth of the country and receive government high-income. Revealed the special role and importance of advertising in the promotion of tourist services in order to inform as many people about the possibilities of digital delivery of these services. Also shown real help from the use of mathematical methods in solving emerging issues.
\end{abstract}

Keywords-digitalization of tourism; the blockchain; digital services; digital advertising; mathematical methods.

\section{INTRODUCTION}

Currently the most urgent task for the Russian economy, recognized at the state level, is its digitization. In essence, you need to create a model of the economy that will work, based on the opportunities provided by the Internet. The number of Internet users is more than half the world's population, so the digital economy in the near future will actively develop, contribute to economic growth worldwide, the development of new innovative industries. Very important Russia does not lag behind in this matter from the highly advanced "electronic" countries, such as Japan, South Korea, USA, Thailand etc. it is recognized that the effectiveness of the digital technologies use in the economy depends on the economic growth of the continent. Speak even of the opinion that companies and industries not connected to digital channels will be thrown out of the world market. In Russia, low level of automation and robotization of production and application of digital technologies in the industry as a whole. The gap between Russia and Germany, USA, Japan, China, South Korea, for the introduction of digital technologies in the economy, according to various estimates, an average of 7-10 years. This gap can lead to the inability of Russia to compete with the leading industrial countries. Therefore, the developed government programme for the digital economy until 2024, with appropriate government support and the joint efforts of science, business and society will lead to the creation of digital ecosystems, will provide a high economic growth rate and subsequently a higher standard of living of the population [1].

\section{LITERATURE REVIEW}

Digitalisation opens up new opportunities and trends that penetrates all areas changes the ways of communication and work organization, forms of learning and leisure. Tourism, of course, is no exception[2,8]. Many analysts agree that hightech development of tourist cluster will bring the state revenues comparable to oil and gas industry. A good example can serve as precedent with the United Arab Emirates, where prosperity, higher living standards began with the discovery of oil in the bowels. Now the reserves of fossil fuels running out, but the state has little depends on them. First came the industry, bringing unprecedented dividends.

The recipient of any service in our time is constantly evolving, growing interest in digital technologies. He creates new questions that are simple "figure" to answer not. People, especially older ones, need live contact with a specialist to discuss certain details and answers to his questions. In the field of tourism services using the digital communication with a live customer contact is a new direction. Travel companies it is important to quickly and reliably bring tourist product both on digital channels and communications (not digital) channels to "prikazivanja" new customers. At this stage, the use of such technological methods (up to the maximum of the transition to digitalization) will provide high-quality services to customers and will help you to be afloat in the competitive market of travel business [3,9].

\section{RESEARCH METHODOLOGY}

What is the digitalization of the economy and the tourism sector specifically? The creation of a new type of worker "digital", which will differ a particular set of knowledge and skills, quickly able to change under the influence of a powerful stream of digital technologies. Particularly rapid digitalization is being implemented in the banking sector, which has long been transactions are conducted online. But there are also observed negative aspects - many workers remain out of work, rising unemployment. Demand expects only "digital employees". This problem applies to many industries, including in the tourism industry[4].

But progress goes by leaps and bounds. The gap between the advanced countries of the world is dangerous and fraught. In Russia it is necessary to develop digital technology to overcome the imbalance in the development of IT technologies among regions of the country in order to parallel all enter into the information society. 
At the beginning of the 21 st century digital services for tourists were created, they became the system of booking and purchasing tickets such as Booking, Aviasales[4]. To choose a destination, book a suitable price hotel, buy tickets online is convenient and fast, so most tourists prefer to use these main components of the process of digitalization of the tourism. Without leaving home you can find the so-called "My world tour", using online resources and search engines. With their help, find the tour that's right for a specific client or family climate and domestic desires, and, most importantly, cheap.

One of the modern forms of digitalization of tourism can be attributed to the active implementation of mobile applications. They are very popular now for getting quick information on a tourist trip. But still the order of the permit requires that any personal data that is difficult to do with mobile devices. Here it is necessary to establish a seamless transition to work with a personal computer, in order not to lose found in the search information.

Another form of tourism is the digitalization of the blockchain. The word "blockchain" became the most popular over the past two years. It means a set of contiguous blocks problem solution, in other words, is a flowchart establishing the procedure of problems resolution. Tourism is one of the areas where the blockchain technology, when used properly, will bring tangible benefits. Because this technology combines all the previous forms of digital tourism, and it can completely change the scope of tourist services. Information about buying tickets, booking rooms in hotels and the loyalty programs will exist in one digital space and will help all parties involved in the provision of services, to focus on the customer and to anticipate his desires[5,10].

It should be noted that area of digitalization of tourism as "wild tourism". Due to the extensive use of free access to the Internet, a large number of tourists plan their own trips without the help of travel agencies. This can be a automobile tourism, mining, water, agriculture. However, for independent tourism it is necessary to possess certain knowledge, to be able to calculate a route, to be aware of the possible dangers and risks outside of their usual habitat. In view of this became the established e-school travel, which helps in the search for tourist itineraries based on individual preferences and available funds. In these e-schools submitted the questions that the tourist is difficult to answer. It is the search of optimal route, selection of carriers, especially Hiking travel, types of accommodation, insurance regulations, questions of customs control. Introduce potential independent tourists with possible risky situations and aid in emergency situations. Given this type of tourism should expand existing online resources, i.e. to carry out remote consultation and training in the form of online training. The creation of a common information base in a network the Internet are a great help in providing quality care in the provision of tourism services.

\section{RESULTS}

As you know, advertising - the engine of progress. Digital advertising of the tourist product is one of the honorable places among the other components of the tourism digitization. In this case, advertising should not irritate, but rather to hold the attention of the client. More important in e- marketing have post feedback about the places of visit. Such comments wave like spread, joined by other network users and the information becomes available to a wider audience. In social networks you should use all methods to attract potential tourists to share exciting photos and videos, inspiring you to travel to beautiful places; share useful information with them; to share experiences. The main thing in the promotion is the creation of the image of a tourist place so really wanted to go there. For this given information should be based on the idea about available benefits and features of this direction, and it is necessary to present compelling and convincing.

Investments in advertising through digital channels are growing every year. So according to some one-third of all costs in the world of digital promotion of tourism products. For example, Israel spends $25 \%$ of advertising budget on digital promotion. A representative of the national Fund for the promotion of Germany in Russia this year decided to allocate $90 \%$ of the marketing budget for the same purpose and explains this high efficiency [6].

In the digital promotion of the tourist product and the role of advertising in this important role of mathematical methods and models. A simple mathematical model of the advertising described in the following task was built [7].

$$
\mathrm{dy} /(\mathrm{dt})=\mathrm{k} * \mathrm{y}(\mathrm{t}) \cdot[\mathrm{N}-\mathrm{Y}(\mathrm{t})], \mathrm{y}(0)=\mathrm{N} / 2 \text {. }
$$

Here $\mathrm{N}$ is the maximum number of potential tourists who know about the product, $y(t)$ - the number of people at time $t$, knowing about the possibility to buy a ticket in a certain direction, $\mathrm{k}>0$ is determined experimentally and depends on the intensity of advertising.

It is assumed that at the beginning of the advertising campaign, the number of consumers who know about the possibility to get the interest of their ticket is half of the total number of potential tourists in this direction.

Received that with the passage of time and the result of a good digital marketing the tourism firm will have a sufficient number of network users, who learned about the presence and wished to purchase the tourism product.

\section{CONCLUSION}

In the article the author analyzes the approaches to rapid and qualitative development of digital tourism in our country. The necessity of involving specialists in many related areas of the economy to address the challenges faced by the tourist business objectives. The role of advertising, as well as the possibility of calculating the number of users of e-tourism product with the help of mathematical methods in digital promotion of tourism services was highlighted.

\section{References}

[1] Hayrapetyan A. S., Grable A. N. Modern strategy of formation and development of the digital economy. "Economics and entrepreneurship". 2017,10(1), pp. 938-943

[2] A meeting of the Commission in the field of "high technologies Development". Astana. 2019

[3] Digital publishing: how does technology affect the tourism industry in the future. - MICE|EVENT| TRAVEL MICE RUSSIA 
domestic tourist market. Revista Publicando. 2018, vol. 5, 18, pp. $213-$ 227.

[4] Cherevichko T. V., T. V. Timakova the Digitalization of the tourism: the forms of. News of Saratov University. 2019, vol. 19, 1, pp. 59-64

[5] [Alexsandr S. Kuznetsov. Russian Professor's meeting. Russian Journal of Physical Education and Sport. 2019, 14(1), pp. 17-22. DOI: 10.14526/2070-4798-2019-14-1-18-24

[6] Cherepova I. H., Cherepova I. A. Mathematical model of advertising in the tourism business. All-Russian scientific - practical conference "Actual problems of priority and innovative technologies of development of the agroindustrial complex of the region." Nalchik, 2014, 360.

[7] Gorbunov A. P., Kolyadin A. P.,Gazgireeva L. Kh., Burnyasheva L. A., Shtapova I. S. Organization of tourist destination to form a competitive
[8] Gorbunov A. P., Kolyadin A. P., Burnyasheva L. A., Gazgireeva L. Kh., Kosenko O. Y. Tourist and recreational clasters as organizational and economic mechanizm of control of formation and development of innovative capacity of the North Caucasus Federal District. Revista "Amazonia Investiga". Periodicidad: Bimestral. 2018, vol. 7, 17, pp. 6071.

[9] Truhachev A. V., Elfimova Yu.M., Varidova S. V., Ivolga A. G. Rural tourism in the implementation of the strategy of agricultural enterprises development in Russia. Reseach Journal of Pharmaceutical, Biological and Chemical Sciences. 2018, vol. 9, 4, pp. 700-705. 